\title{
Use of Recycled Aggregates in Concrete
}

\author{
Nadjoua Bourmatte ${ }^{1}$, Hacène Houari²
}

\begin{abstract}
Concrete recycling is becoming an increasingly popular way to utilize aggregate left behind when structures or roadways are demolished. In the past, this rubble was disposed of in landfills, but with more attention being paid to environmental concerns, concrete recycling allows reuse of the rubble while also keeping construction costs down; This research is conducted on the use of concrete demolition waste; this product has a specific effect on the behaviour of the fresh and hardened concrete. The research program therefore includes work on the valuation of this Waste as well as the development of new materials: concretes based on these recycled aggregates with integration of Algerian raw materials.

We chose as basic parameters: The origin of the waste: demolition of concrete, the substitution rate of recycled aggregates: $0 \%-25 \%$ $50 \%$ and $100 \%$ and the variation of the cement content: $250-350$ and $450 \mathrm{Kg} / \mathrm{m} \mathrm{3}$. By studying these parameters, we observed the behaviour in fresh and solid state of concrete elaborated with recycled aggregates. Recycled concrete aggregates are generally more absorbent and less dense than ordinary aggregates. The shape of aggregates is similar to that of crushed rock. Concretes made with aggregates from recycling have good qualities of manoeuvrability, durability and resistance to the action of freezing-thawing. Compressive strength varies with the initial strength and the water-tocement ratio of the new concrete. As with any new source of aggregate, we must check durability, size and properties of aggregates.
\end{abstract}

Keywords_-Recycled aggregates, recycling, demolished concrete, compressive strength.

\section{INTRODUCTION}

$\mathrm{I}_{\mathrm{T}}^{\mathrm{T}}$ is necessary to effectively reuse construction and demolition waste in order to conserve nonrenewable natural aggregate resources and alleviate the pressure on finding new disposal sites to manage the wastes. Recycling and reusing of construction and demolition waste as coarse aggregates for new concrete facilitate its large-scale utilization. Among all the construction and demolition wastes, waste concrete occupies a large percent. The use of waste materials as a source of aggregate in new construction materials has become more common in the recent decades. The depletion of the existing landfills and the scarcity of natural resources for aggregates encourage the use of construction and demolition construction and demolition waste as a source of aggregates in the production of new concrete.

Over the last decades, large amount of experimental works have been carried out to investigate the material properties and durability of recycled aggregate concrete.

Since no reduction in safety or lifetime of the work is acceptable, studies on effect of the substitution rate of recycled

\footnotetext{
12 University of Frères Mentouri, Laboratory LMDC, Constantine-Algeria
}

aggregates on the properties of these concretes appear to be a necessary step in order to assign a field of use to it. The research program therefore includes work on the valuation of construction / demolition waste, as well as the development of new materials and products (recycled aggregates-based concrete) with integration of Algerian raw materials.

\section{EXPERIMENTAL DETAILS}

\section{A. Materials}

CPJ 45 cement is used in different concretes. Natural and recycled aggregates were used in the concrete mixtures. In this study, recycled aggregate sourced from a laboratory specimens crushed was used.

The resulting granular classes are: Recycled aggregates (demolished concrete):

Sand 0/6, Gravel 6/12, Gravel 12/20, the characteristics of these aggregates are presented in Table 1.

TABLE I: CHARACTERISTICS OF THE DEMOLITION CONCRETE AGGREGATE

\begin{tabular}{l|cccc}
\hline Class & Class & $\begin{array}{c}\text { Class } \\
\text { Test }\end{array}$ & $\begin{array}{c}\text { Class } \\
12 / 20\end{array}$ & Value limit \\
\hline Flattening coefficient & & $11 \%$ & $14 \%$ & $<30 \%$ \\
Equivalent of sand & $95 \%$ & & & $>65 \%$ \\
Bleu Methylene test & 0.38 & & & $<1$ \\
Bulk density & 1.35 & 1.24 & 1.23 & $<40 \%$ \\
Los Angeles test & & $27 \%$ & $25 \%$ & \\
Micro-Deval test & & $31 \%$ & & \\
\hline
\end{tabular}

\section{B. Testing Parameters}

Substitution rate of recycled aggregates (concrete demolition): 0\%, 25\%, 50\% and 100\% respectively to achieve concretes BR0, BR25, BR50 and BR100.

Cement content: 250 - 350 - $450 \mathrm{Kg} / \mathrm{m}^{3}$

Abrams cone slumping is 6 to 9 .

The composition of concrete is made according to the method "Dreux - Gorisse"

Cylindrical test specimens of dimensions 16 X32 cm are made to measure the compressive strength of concrete, and other prismatic 7 X7X28 Cm for the determination of tensile strength of concrete. The test pieces are stored in water at a temperature of $20^{\circ} \pm 1 \mathrm{c}$ until rupture deadlines.

\section{RESULTS AND DisCUSSIONS}

\section{A. Compressive Strength of Concrete}

The development of compressive strength of concretes is shown in figure 1, It can be seen that at all cement dosages, the compressive strength values of the concrete mixtures prepared with recycled aggregates were significantly lower than for the corresponding concrete mixtures prepared with natural 
aggregate. The compressive strength of concrete mixture prepared with $50 \%$ of recycled aggregates satisfied the designed 28-day strength of $21.75 \mathrm{MPa}$, and it was similar or slightly higher than that of the concrete mixture prepared with natural aggregate only.
It can be seen that the compressive strengths of the concrete made with $25 \%$ and $100 \%$ were respectively lower than for the corresponding natural aggregate concrete. But the compressive strength of the BR50 made with 50\% recycled aggregates and BR0 was equal to than that of the natural.

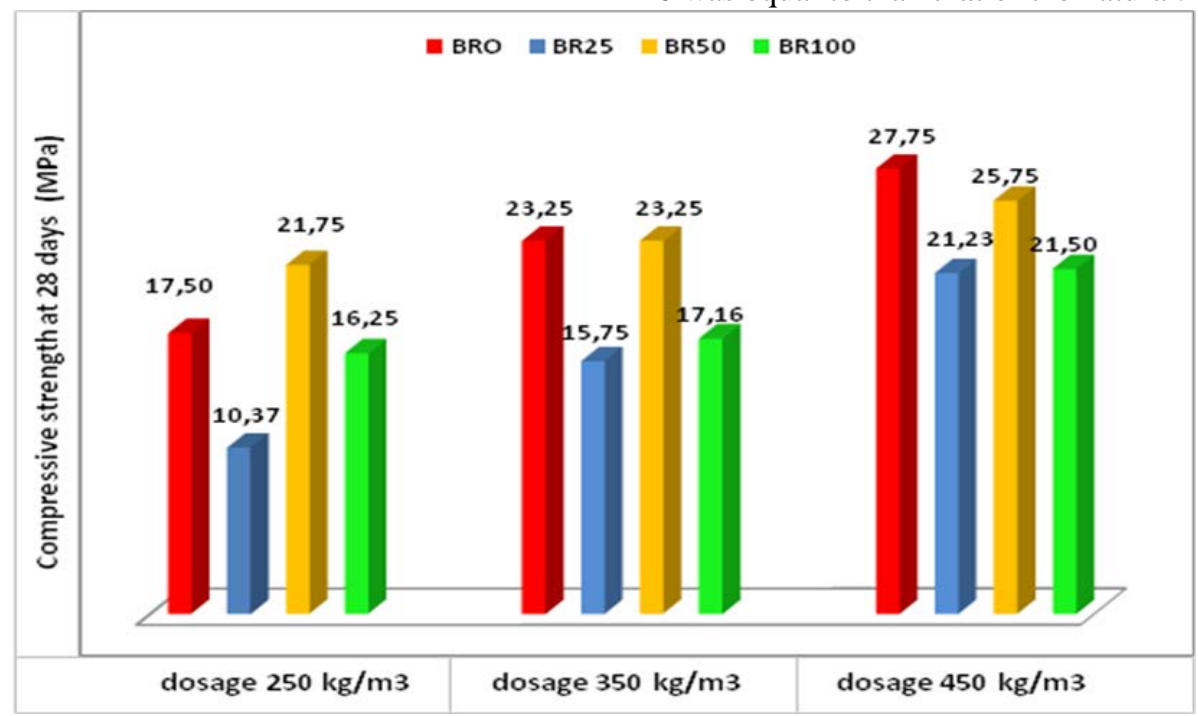

Fig. 1: Compressive strength of concrete at 28 days according to the cement content

\section{B. Tensile Strength of Concrete}

The tensile strengths of the various concrete specimens are given in figure 2, It can be seen that before 28 days, the tensile strength of the concrete prepared with recycled aggregate derived from parent concretes with different strength grades was lower than that of the natural aggregate concrete.

At cement dosage of $450 \mathrm{Kg} / \mathrm{m}^{3}$, the tensile strength of the concrete with recycled aggregate was higher than that of the control concrete at 28 days. It can be seen that at cement dosage of $350 \mathrm{Kg} / \mathrm{m}^{3}$ the tensile strengths of the concrete BR0 and BR50were respectively equal. At the longer curing date, the concrete mix prepared with recycled concrete aggregates had higher tensile strength and this may due to the porous nature of the recycled aggregates improving the microstructure of the new concrete.

The better contribution of recycled aggregates to the tensile strength may be due to the porous nature of the recycled aggregates and this improved the microstructure of the Interfacial Transition Zone between the new cement paste and the recycled aggregates leading to improved bond strengths.

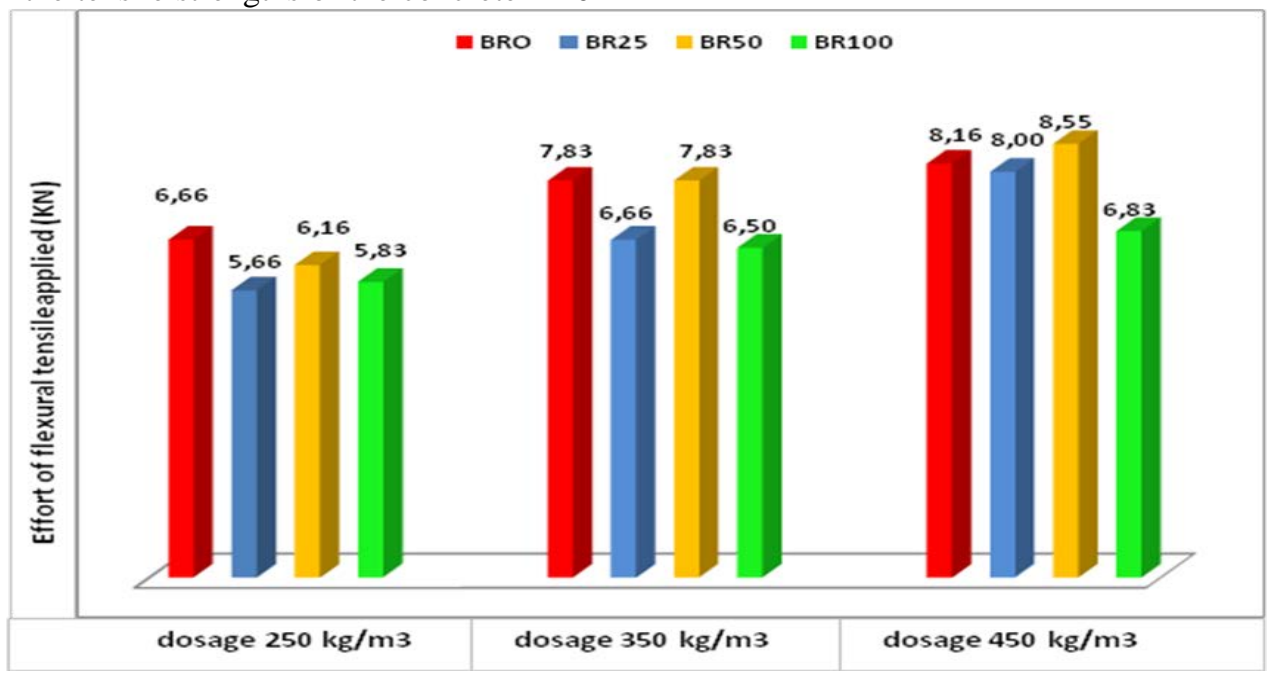

Fig.2: Tensile strength of concrete at 28 days according to the cement content

\section{CONCLUSION}

Based on the experimental results, the following can be concluded:

One of the parameters affecting most the properties of either fresh or solid concrete, include the characteristics of aggregates and cement content.
We must prevent dirt, drywall, wood and other external substances from contaminating the final product.

These aggregates can be used in foundation layers as in lean concrete, in cement-soil and as the only source of aggregates or partial replacement of aggregates in new concrete. 
The strength of recycled aggregates concrete can be increased by lowering the water-binder ratio if water reducers are used to provide the adequate workability.

The type of recycled aggregate and the percentage of replacement are the factors that clearly influenced the most properties, especially the absorption and the occluded air.

The variability of the properties of old concrete, which influences the new ones, is one of the main concrete recycling problems. It can partially be avoided by frequently checking the properties of old concrete being recycled, it may be then necessary to adjust dosages.

Compressive strength varies according to the strength of the original concrete and the water-to-cementing ratio of the new concrete.

We can increase it by using higher binder content and replacing part of the recycled concrete by ordinary aggregates.

Concrete made with $100 \%$ of recycled coarse aggregates has $20-25 \%$ less compression strength than conventional concrete at 28 days, with the same effective w/c ratio $(\mathrm{w} / \mathrm{c}=0.50)$ and cement quantity

Concrete made with $100 \%$ of coarse recycled aggregate requires high amount of cement to achieve a high compressive strength and consequently is not an economic proposition as it is not cost effective. These recycled aggregates should be used in concretes with low-medium compression strength (20- 45 $\mathrm{MPa})$.

\section{REFERENCES}

[1] Dominogo-Cabo A, Lazaro C, Lopez-Gayarre F. Creep and shrinkage of recycled aggregate concrete. Construction and Building Materials, 2009, 2545-2553.

http://dx.doi.org/10.1016/j.conbuildmat.2009.02.018

[2] Evangelista L, Brito J. Mechanical behaviour of concrete made with fine recycled concrete aggregates. Cement and Concrete Composites, 2007, 397-401.

http://dx.doi.org/10.1016/j.cemconcomp.2006.12.004

[3] Etxeberria M, Vazquez E, Mari A, Barra M, Influence of amount of aggregates production process on properties of recycled aggregate concrete. Cement and Concrete Research, 2007, 735-742. http://dx.doi.org/10.1016/j.cemconres.2007.02.002

[4] Corinaldesi V, Moriconi G, Influence of mineral additions on the performance of $100 \%$ recycled aggregate concrete, Construction and Building Materials,2009, 2869-2876. http://dx.doi.org/10.1016/j.conbuildmat.2009.02.004

[5] Corinaldesi V, Mechanical and elastic behaviour of concretes made of recycled-concrete coarse aggregates, Construction and Building materials,2010, 1616-1620. http://dx.doi.org/10.1016/j.conbuildmat.2010.02.031

[6] Jure Grdic Z, A.Toplicic G, M.Despotovic I, S.Risti. Properties of self compacting concrete prepared with coarse recycled concrete aggregate, Construction and Building Materials, 2010, 1129-1133. http://dx.doi.org/10.1016/j.conbuildmat.2009.12.029

[7] Bauchard M, Bétons de démolition, Valorisation et élimination des déchets et sous-produits industriels et urbains, journée de bilan de l'action de Recherche $\mathrm{N}^{\circ} 36,4$ et 5 Mai 1983, 389-393.

[8] Bernier G., le recyclage de béton sous forme de Granulats, Thèse de Doctorat, Université Paris VI, France, 1983.

[9] Charlot-Valdieu C. et G. Sandret, les travaux du groupe de travail européen "Construction et Démolition Waste», Compte rendu du colloque BTP : Démolition et Valorisation des déchets ; ADEME et DHC , Paris, 1995.

[10] Larbi J.A and P.D Steijaret, Microstructure of concretes containing artificial and recycled aggregates, Environmental aspects of construction with waste matérials, Elsevier Science, 1994, 877-888.
[11] Morel A, Comment prendre en compte les préoccupations environnementales. Recyclage et gestion des déchets de chantier, PLASTIBAT- premières rencontres des matériaux de synthèse avec le BTP, 1995.

[12] Simons B., Vynke J, Les déchets de construction et de démolition, C.S.T.C. Magazine, 1993, 326-341.

[13] Hadjieva-Zahariev R, Durabilité des bétons à base de granulats recyclés. Thèse de Doctorat. Université d'Artois, France, 1998.

[14] Mesbah HA, Amélioration du comportement des mortiers à base de granulats recyclés par adjunction des fibres, Thèse de Doctorat, Université d'Artois, France, 1997. 